\title{
Effects of Professional Skepticism, Organizational-Professional Conflicts and Performance Evaluation Toward Audit Judgment Through Auditor Dysfunctional Behavior
}

\author{
Nurazmi Safitri Haris \\ Economics and Business Department, Airlangga University, Indonesia
}

\begin{abstract}
The research is financed by Asian Development Bank. No. 2006-A171(Sponsoring information)
\end{abstract} Abstract

The role of internal auditor is still very much needed in helping to ensure governance in developing countries such as Indonesia. Fraud actions such as corruption, manipulation of financial statements and embezzlement of funds which have occurred in Indonesian government are still alarming, so that internal auditor becomes public spotlight. Weak supervision is suspected to be a major factor in corruption cases. The internal auditor as the Government Internal Supervisory Apparatus (APIP) has a role as supervisor, assistant and protector of management, as well as being an independent advisor to the government which should be able to prevent fraud which could harm the country. This study aimed to empirically prove the correlation of professional skepticism, organizationalprofessional conflict and performance evaluation toward Audit Judgment with auditor dysfunctional behavior as a moderating variable. This research was conducted on the auditor of the Government's Internal Supervisory Apparatus who worked in the Financial Supervisory Agency and Development Representative of East Java Province and the Inspectorate of East Java Province. Sampling was done by purposive sampling method. Questionnaires which were successfully collected were 81 questionnaires. The results showed that Professional Skepticism, Organizational Professional Conflict and Performance Evaluation had an effect on audit judgment, but auditor dysfunctional behavior could not moderate the influence of professional skepticism, professional organizational conflict and performance evaluation of audit judgment.

Keywords: Professional Skepticism, Organizational-Professional Conflict, Performance Evaluation, Audit Judgment, and Auditor Dysfunctional Behavior.

DOI: $10.7176 /$ RJFA/10-8-16

Publication date: April $30^{\text {th }} 2019$

\section{Introduction}

The potential of fraud in the management of state finances is commonly happened. Weak supervision is suspected to be a major factor in corruption cases. Corruption has become a common national issue in recent years and based on the release of Indonesia Corruption Watch in February 2018, the handling of corruption cases in 2017 has increased significantly compared to 2016, especially from the aspect of state losses which increased to 6.5 Trillion Rupiah in 2017.

The efforts to reduce corruption rates has not been easy. In general, the audit profession, including internal government auditors, is the first efficient defense mechanism to prevent and detect fraud in the government. The internal auditor as the Government Internal Supervisory Apparatus (APIP) has a role to supervise, assist, and protect the management, as well as being an independent advisor to the government so as to prevent fraud (Ferry et al., 2017).

As a Government Internal Supervisory Apparatus, the auditor also makes judgment on financial statements and various types of fraud which appear in financial statements. Looking at the auditor's duty also to make an assessment, the auditor is required to have the ability to process information to determine judgment at the time of the audit assignment (Mangoting, 2004). Therefore, the auditor will be careful in carrying out the duties and determine the judgment will be given because the auditor's professional responsibility does not stop until the report is submitted to the client. The auditor will be responsible for the contents of the statement signed and decision making regarding the opinions issued by the auditor.

Auditor decision making is an important element that can affect audit quality. Audit quality will be a guarantee function that is used to compare conditions which have been set with actual conditions, and the audit report is considered to have quality if the auditor carries out his work professionally, adheres to auditing standards, has sufficient evidence, competent and does not ignore procedure steps of audit. Because of the importance of audit quality, an auditor is not allowed to take deviant actions or behaviors that can reduce audit quality, which is Dysfunctional Audit Behavior.

Several previous studies have found out what factors influence audit judgment. Popova's (2012) study showed that skepticism is an important trait in audit which has been emphasized in recent years, because a lack of professional skepticism is at the beginning of audit failure and will cause loss of trust from investors; Operasianti et al. (2014) found that professional skepticism has a significant and positive influence on audit judgment; and the 
results of Winardi and Permana's study (2015) showed that professional skepticism influences the auditor's assessment of fraud. The research is in line with Nolder (2012) who stated that professional skepticism provides strong theoretical support to enrich understanding.

In addition to professional skepticism, this study also examined the effect of professional organizational conflict on audit judgment. Iswari and Kusuma's (2013) study found that organizational-professional conflict has an influence on audit judgment. Heyrani et al. (2016) showeda that professional judgment influences conflicts between auditors and management. Also, research conducted by Vinciguerra (2002) showed that the pressure felt by auditors has a significant influence on all audit assessments.

This study also examined the effect of performance evaluation on audit judgment. Research conducted by Mertzlufft (2000) showed that the expectation of a differential review affects audit judgment and justification in all levels of audit risk.

The purpose of this study was to empirically prove the correlation of professional skepticism, organizationalprofessional conflict and performance evaluation of Audit Judgment through auditor dysfunctional behavior.

Based on harmful cases to the country which still commonly happen, I am interested in conducting this research to find out the reason why these cases still occur, and auditors are still involved in these cases. On the other hand, auditors currently get the spotlight from the public in various countries due to the increasing demand for quality audit reports from users of financial statements. In addition, this research is also important for public accountants or accountants in the government to understand the various factors associated with audit dysfunctional behavior and to assist accountants in an effort to prevent auditors from performing dysfunctional audit behaviors, taking audit judgments that do not make conflict with professional standards, and can avoid fraud which can harm the reputation of both the accountant and the profession.

The object used in this study was the auditor who worked in the representative of the BPKP East Java Province and the Inspectorate of East Java Province. Data was collected by using questionnaires sent to auditors of BPKP Representatives of East Java Province and Inspectorates of East Java Province. The number of questionnaires sent was 150 questionnaires and the number of questionnaires which were returned were 81 questionnaires. The data analysis technique in this study was done by Statistical Package for Social Science software version 21.

The results showed that Professional Skepticism, Organizational-Professional Conflict and Performance Evaluation had an effect on audit judgment, but auditor dysfunctional behavior could not moderate the influence of professional skepticism, organizational-professional conflict and performance evaluation of audit judgment. This study provided several implications including professional skepticism as an important component to protect audit failures in the future, then the auditors involved in conflict sometimes neglected professionalism and were vulnerable to deviant behavior which also tend to influence professional judgment. Performance evaluation was also considered as an important tool used to control audit quality so as to produce a good audit assessment.

In the next section, this paper will discuss the literature review and hypothesis, research design, research results, and conclusion from this study.

\section{Literature Review}

\subsection{Attribution Theory}

This theory was initially introduced by Fritz Heider, a senior psychologist from Germany. According to Luthans et al. (1987), this theory states about how an individual can explain the causes of their own behavior or the behavior of others. Attribution theory is used to explain the relationship of auditor dysfunctional behavior and audit judgment caused by professional skepticism, professional organizational conflict, and performance evaluation. In accordance with attribution theory, if the auditor performs the duties based on existing procedures, the results will also be optimal. The results obtained can be due to internal factors, both from the individual and external results such as the work environment of the auditor.

\subsection{Role Theory}

Role theory states that if the behavior expected by an individual is inconsistent, the person will experience stress, become dissatisfied, and do something ineffective than when there is no conflict (Rizzo et al., 1970). The role theory in this study related to the role of conflict that the auditor has two roles as a professional who should be subject to the ethics code of professional accountants and members of the organization.

\subsection{Cognitive Theory}

Cognitive theory is a theory which considers both the social origins of human thought (what individuals learn by being part of society) and the cognitive processes of human motivation (Bandura and Cervone,1986). The researcher used this theory as a literature to explain the effect of auditor dysfunctional behavior on audit judgment. Based on cognitive theory, auditors who carry out audits are in line with audit procedures, so they will avoid audit dysfunctional behavior, and vice versa, auditors who do not follow audit procedures correctly during the audit process will be motivated to accept auditor's dysfunctional behavior. 


\subsection{Hypothesis Development}

2.4.1 Effect of professional skepticism to audit judgment.

Nolder's research (2012) showed that professional skepticism provides strong theoretical support to enrich understanding because professional skepticism is considered as socially inherited attitude that consists of beliefs about the adequacy of evidence in response to risks and trends in actions related to the nature and extent of audit procedures which is done. Aghazadeh's research (2012) made auditors aware of characteristics, such as expressions of belief, which can cause them to use a lower level of skepticism. The skepticism of a professional auditor must manifest itself in the choice of audit procedures carried out to provide sufficient and competent evidence to support the audit opinion, given the risks which are considered to be relevant. Auditors are required to be skeptical in carrying out audits because if the auditor passes a professional assessment, it can lead to wrong decisions that will have a negative impact on audit quality. In general, individuals who have a higher level of professional skepticism will make better and ethical audit judgments. Therefore, the researcher made the hypothesis as follows:

H1: Professional Skepticism was significantly and positively correlated to Audit Judgment.

2.4.2. Effect of organizational-professional conflict to audit judgment

Research done by Vinciguerra (2002) showed that pressure and self-interest threats to accept the accounting treatment proposed by the auditee have a statistically significant influence on all audit judgments. Heyrani et al. (2016) revealed that the higher the conflict between auditors and management, the higher the level of professional judgment. The research of Iswari and Kusuma (2013) found that professional organizational conflict influences audit judgment.

An auditor who experiences conflict between organizational values and professionalism will have tendency to have deviant behavior during audit assignments. Deviant behavior that tend to influence professional judgment must be deviated from the applicable standards too. Therefore, conflicts between clients and auditors can influence the judgment given by the auditor so that the hypothesis was made as follows:

H2: Organizational-professional conflict was significantly and positively influenced Audit Judgment.

2.4.3. Effect of performance evaluation to audit judgment

Mertzlufft (2000) stated that the expectation of differential review influences audit judgment and justification throughout the level of audit risk. While the research of Lin et al. (2003) showed that performance evaluations between auditors working in small companies differed from large auditors because auditors from small companies in England only assessed performance at a moderate level. Trotman (1985) showed that judgment made after a review is significantly more accurate than before.

The researcher expected that when the performance evaluation was carried out, the resulting judgment would be better and more accurate. The next hypothesis is as follows:

H3: Performance evaluation was significantly and positively influenced Audit Judgment

2.4.4. Effect of professional skepticism to the behavior to dysfunctional auditor

Popova (2012) study showed that skepticism is an important trait of audit which is highly emphasized, because a lack of professional skepticism is the beginning of audit failure. The results of the study by Septiani and Sukartha (2017) showd that the variable of professional skepticism negatively influences the acceptance of auditor dysfunctional behavior.

Auditors with high professional skepticism may doubt the evidence that the statement is true rather than doubt the evidence that the statement is wrong, and will tend to gather relatively more evidence as a result. Therefore, the higher the professional skepticism of an auditor, the auditor does not accept audit dysfunctional behavior that can cause a decline in audit quality.

H4: Professional skepticism significantly and negatively influenced Disfunctional Auditor.

2.4.5. Effect of organizational professional conflict to dysfunctional auditor

Shafer et al. (2002) showed that selfishness tends to encourage employees to behave unethically and tend to encourage employees to behave dysfunctional. Fakhara and Hoseinzadeh (2016) research shows that professional commitment and organizational commitment have a relationship with the auditor's dysfunctional behavior. Svanberg and Öhman's (2016) research showed that there is a positive relationship between the conflict of professionals and actions to reduce audit quality.

Researchers suggested that auditors who work in organizations that make demands are not in accordance with professional responsibilities, then the possibility of auditors will conduct dysfunctional behavior. The more there is no conflict between the organization and professionals experienced by the auditor, the lower the level of acceptance of dysfunctional behavior.

H5: Organizational Professional-Conflict was significantly and negatively affected Auditor's Dysfunctional Behavior.

2.4.6. Effect of performance evaluation to auditor's dysfunctional behavior

Beekes et al. (2014) showed that dysfunctional behavior will increase when performance evaluations focus on achieving predetermined targets. Andiola's research (2014) found results that feedback from auditor performance 
is an important component in the audit environment to ensure quality control and to develop and train auditor staff. Researcher expected that when auditors are expected to be evaluated, they will improve their performance so that they can reduce dysfunctional behavior. The next hypothesis is:

H6: Performance evaluation was significantly and negatively affected Auditor's Dysfunctional Behavior.

\subsubsection{Effect of auditor's dysfunctional behavior to Audit Judgment}

Ismail (2015) said that acceptance of dysfunctional behavior is significantly affected audit judgment. The result of this study was in line with the research of Heyrani et al. (2016) who stated that if the auditor passes a professional assessment, then this can lead to wrong decision making which will have a negative impact on audit quality. Rokhmani and Malikah's research (2018) found that auditor's dysfunctional behavior significantly affected audit judgment. The researcher concludes that the higher the acceptance of dysfunctional behavior, the auditor will be unethical in decision making, and vice versa, auditors who behave functionally will be more ethical in audit decision making decisions. The next hypothesis was:

H7: Auditor's dysfunctional behavior was significantly and negatively affected Audit Judgment.

\subsubsection{Effect of Professional Skepticism on Audit Judgment through Auditor Dysfunctional Behavior}

Based on the results of previous studies described above, the auditor must have skepticism when making judgment in the audit in order to obtain the right decisions and can reduce the acceptance of dysfunctional behavior resulting in good audit quality. Therefore, the next hypothesis proposed by the researcher is as follows:

H8: Professional skepticism was significantly and positively affected Audit Judgment through Auditor Dysfunctional Behavior.

2.4.9. Effects of Organizational-Professional Conflict on Audit Judgment through Auditor Dysfunctional Behavior One of the factors that can trigger professional organizational conflict is the relative strength in negotiations between the two parties which can sometimes make the auditor ignore the professionality. Thus, the more there is no conflict between the organization and the professional experienced by the auditor, the lower the acceptance of dysfunctional behavior which will then have an impact on the assessment carried out by the auditor. Therefore, the following hypothesis proposed by researchers is:

H9: Professional-Organization Conflict had a significant and positive effect on Audit Judgment through Auditor Dysfunctional Behavior.

\subsubsection{Effects of Organizational-Professional Conflict on Audit Judgment through Auditor Dysfunctional Behavior}

A group of audit research has discussed behavior that may be directly or indirectly related to the quality of the audit, including the collection of insufficient evidence, flaw audit procedures, inaccuracies, acceptance of weak client explanations, and so on. Researcher expected that when auditors was evaluated, they will improve their performance so that they can reduce dysfunctional behavior and will affect audit assessment, therefore the last hypothesis in this study is as follows:

H10: Performance Evaluation has a significant and positive effect on Audit Judgment through Auditor Dysfunctional Behavior.

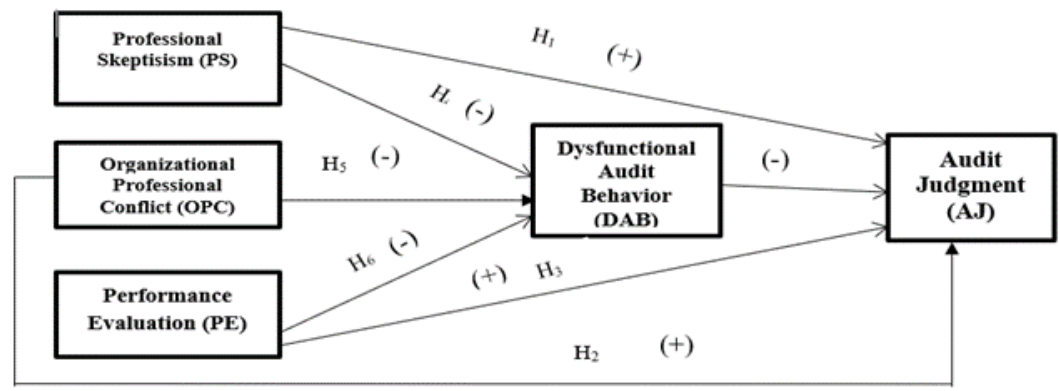

Figure 1 : conceptual framework

\section{Methods of Research}

Professional skepticism is the important audit nature which is intrinsic to the audit process and provide a basis for detecting fraud (Khan et al., 2015). Professional skepticism was measured using several indicators developed by (Hurt, 2010), namely: Interrogative, careful attitude in making decisions, the existence of curiosity, interpersonal understanding, self-confidence, and the auditor's belief.

Organizational-Professional Conflict (OPC) is the result of conflict between organizational and professional commitment, as a result of disputes between professional values and organizations (Svanberg and Öhman, 2016). The scale of conflict of professional organizations contains two items. First, this scale measures the level of respondents' perceptions of organizational-professional conflict. The second measures of organizationalprofessional conflict which is inferred from the relationship between organizational and professional commitment. Performance evaluation is an important tool that can be used to monitor audit quality, develop and train auditor 
staff in an audit environment, and become a motivational resource in the organization (Andiola, 2014). This study used the audit steps to measure performance evaluation, namely planning, implementation and reporting stage.

Audit dysfunctional behavior is behavior that contributes to a decrease in audit quality later which in turn will lead to audit failure (Yuen et al., 2013). The indicators used to measure auditor dysfunctional behavior are completion of audit steps which are too early, give report of short audit time, lack of evidence, errors made during the audit phase, and errors in providing audit reports.

Audit Judgment is the auditor's personal judgment or the auditor's perspective in responding information which can influence the evidence and decision making on the financial statements of a company (Sofiani, 2015). To measure audit judgment variables, researcher used several indicators such as consideration of materiality and consideration of the level of risk

This study used primary and secondary data sources. Primary data is data which source is obtained directly from the source. In this study, researcher used primary data from questionnaires distributed to research respondents (BPKP Representatives of East Java Province and Inspectorate of East Java Province). Secondary data is data which source had been there before, and researcher used literature, journals, books and other references.

The object used in this study was the auditors who work as the Government Internal Supervisory Apparatus (APIP) in the East Java provincial government. The unit of analysis in this study was the individuals who were the auditor who worked at the BPKP Representative of East Java Province and the Inspectorate of East Java Province. Data analysis techniques in this study was using SPSS version 21 software.

The testing method of the influence of mediation was carried out with two analysis, namely analysis without using mediation and analysis using mediation variables. Researcher used path analysis with a significance level of $1 \%, 5 \%$, and $10 \%$ to test them. The path analysis equation used in this study was:

$\mathrm{DAB}=\beta 1(\mathrm{PS})+\beta 2(\mathrm{OPC})+\beta 3(\mathrm{PE})+\mathrm{e} 1 \ldots . .(1)$

$\mathrm{AJ}=\beta 4(\mathrm{PS})+\beta 5(\mathrm{OPC})+\beta 6(\mathrm{PE})+\beta 7(\mathrm{DAB})+\mathrm{e} 2 \ldots \ldots .(2)$

To test the hypothesis, the researcher used criteria by using mediation requirements developed by (Baron and Kenny, 1986) :

Step $1: A J=\beta 1(P S)+\beta 2(\mathrm{OPC})+\beta 3(\mathrm{PE})+\mathrm{e} 1$

On the condition that the effect of professional skepticism, organizational-professional conflict, and performance evaluation to audit judgement must be positive and significant.

Step $2: \mathrm{DAB}=\beta 4(\mathrm{PS})+\beta 5(\mathrm{OPC})+\beta 6(\mathrm{PE})+\mathrm{e} 2 \ldots \ldots \ldots . .(2)$

On the condition that effect of professional skepticism, organizational-professional conflict, and performance evaluation to audit judgement must be positive and significant.

Step $3: A J=\beta 7(P S)+\beta 8(\mathrm{OPC})+\beta 9(\mathrm{PE})+\beta 10(\mathrm{DAB})$ e 1

On the condition that auditor's disfunctional behavior $(\mathrm{Z})$ had positive and significant effect to audit judgment $(\mathrm{Y})$. Step $4: A J=\beta 7(P S)+\beta 8(\mathrm{OPC})+\beta 9(\mathrm{PE})+\beta 10(\mathrm{DAB})$ e1

Step 4 would be categorized based on the result of testing as follows (Hair et.al., 2010):

It was stated that perfect mediation would occur if professional skepticism, organizational-professional conflict, and performance evaluation did not affect audit judgment after the inclusion of auditor dysfunctional behavioral variables. It was stated that partial mediation would occur if the influence of professional skepticism, organizational-professional conflict and performance evaluation of audit judgment decreased but were still significant after the inclusion of the mediating variable of auditor dysfunctional behavior. It was stated that there was no partial mediation if there was the influence of professional skepticism, organizational-professional conflict, and performance evaluation of audit judgment and did not change when there was a variable mediating auditor dysfunctional behavior.

\section{Result and Discussion}

Based on the results in step 1, it could be concluded that professional skepticism had a significant effect on audit judgment. It proved that the greater the skepticism of the auditor, the more favorable and ethical judgment would be. The result of this study was also in line with the research conducted by Operasianti et al. (2014); Popova (2012); Nolder (2012); Aghazadeh (2012); in which professional skepticism had a significant and positive effect on audit judgment.

Professional skepticism was an important trait that must be owned by the auditor for the assessment of fraud risk because with the attitude of professional skepticism, the auditor would be more sensitive to fraud which was burdened by material misstatements (Winardi and Permana, 2015). This result supported attribution theory which stated that if the auditor performs his duties based on existing procedures, the results will also be optimal. When the auditor has a great attitude of skepticism, it will affect the auditor's assessment to be better and more accurate. The results obtained could be due to internal factors both from the individual itself and external results such as the work environment of the auditor. With the skepticism, the auditor would always question the validity of the evidence obtained during the audit process and made a critical assessment so that if the auditor who had an attitude of skepticism, would produce better judgment and had good audit quality. 
Table 1 test result : Effects of Professional Skepticism, Professional Organizational Conflict, and Performance Evaluation on Audit Judgment

\begin{tabular}{|c|c|c|c|c|c|c|c|}
\hline \multirow{2}{*}{\multicolumn{2}{|c|}{ Model }} & \multicolumn{2}{|c|}{$\begin{array}{l}\text { Unstandardized } \\
\text { Coefficients }\end{array}$} & \multirow{2}{*}{$\begin{array}{l}\text { Standardized } \\
\text { Coefficients } \\
\text { Beta }\end{array}$} & \multirow{2}{*}{$\mathrm{t}$} & \multirow{2}{*}{ Sig. } & \multirow{2}{*}{ Note } \\
\hline & & B & $\begin{array}{l}\text { Std. } \\
\text { Error }\end{array}$ & & & & \\
\hline \multirow[t]{4}{*}{1} & (Constant) & 0,625 & 3,234 & & 0,193 & 0,847 & \\
\hline & $\begin{array}{l}\text { Professional } \\
\text { Skeptisism }\end{array}$ & 0,506 & 0,036 & 0,820 & 14,001 & 0,000 & significant \\
\hline & $\begin{array}{l}\text { Organizational } \\
\text { professional } \\
\text { conflict }\end{array}$ & 0,202 & 0,073 & 0,267 & 2,769 & 0,007 & significant \\
\hline & $\begin{array}{l}\text { Performance } \\
\text { Evaluation }\end{array}$ & $-0,110$ & 0,036 & $-0,276$ & $-3,028$ & 0,003 & significant \\
\hline
\end{tabular}

Dependent Variable: Audit Judgment

Based on the results in step 1, it could be concluded that professional skepticism had a significant effect on audit judgment. It proved that the greater the skepticism of the auditor, the more favorable and ethical judgment would be. The result of this study was also in line with the research conducted by Operasianti et al. (2014); Popova (2012); Nolder (2012); Aghazadeh (2012); in which professional skepticism had a significant and positive effect on audit judgment.

Professional skepticism was an important trait that must be owned by the auditor for the assessment of fraud risk because with the attitude of professional skepticism, the auditor would be more sensitive to fraud which was burdened by material misstatements (Winardi and Permana, 2015). This result supported attribution theory which stated that if the auditor performs his duties based on existing procedures, the results will also be optimal. When the auditor has a great attitude of skepticism, it will affect the auditor's assessment to be better and more accurate. The results obtained could be due to internal factors both from the individual itself and external results such as the work environment of the auditor. With the skepticism, the auditor would always question the validity of the evidence obtained during the audit process and made a critical assessment so that if the auditor who had an attitude of skepticism, would produce better judgment and had good audit quality.

Based on the results in step 1, it could be concluded that professional organizational conflict had a significant effect on audit judgment. This result was in line with the research of Iswari and Kusuma (2013); Heyrani et al. (2016); Vinciguerra (2002); which showed that professional organizational conflict influences audit judgment. The results of this study indicated that the more frequent conflicts between organizations and professionals, the higher the assessment carried out. Conflicts between organizational values and professional values could also have an impact on the assessment of work outcomes.

Auditors have two roles: the guardians of public interests and participants in profit-generating companies where client services are very important (Vinciguerra, 2002). The results of this study supported a role theory by Rizzo et al. (1970) which stated that when the behavior expected of a person is inconsistent with one type of role conflict, the person will experience stress, become dissatisfied, and perform less effectively than if the expectations are not contradictory. In this condition, an auditor could feel there was a conflict between the values adopted in the organization and the values that must be respected by the profession, so there was a role conflict in itself that could affect the auditor's judgment.

Based on the results in step 1 , it could be concluded that performance evaluation significantly influenced audit judgment. This result was in line with research conducted by Mertzlufft (2000) which found that differential reviews affected audit valuation and justification throughout the level of audit risk. The results of this study were also in line with the research conducted by Lin et al. (2003).

Performance evaluation was an important part in almost all organizations because it was related to the development and motivation of resources. Performance evaluation could help increase motivation and job satisfaction from individuals. In addition, performance evaluation could help improve assessment and decision making so that it could produce a good decision. The importance of the review process is often emphasized in the audit literature (Trotman, 1985). The performance evaluation carried out would have an impact on the auditor's assessment and affect the next assignment. When a performance evaluation was given to the auditor and got negative feedback, it would indirectly put pressure to improve performance in the next period and negative feedback provided by the auditor would generally lead to a less ethical assessment. 
Table 2 test result: Effects of Professional Skepticism, Professional Organizational Conflict, and Performance Evaluation on Dysfunctional Audit Behavior

\begin{tabular}{|c|c|c|c|c|c|c|c|}
\hline \multirow[b]{2}{*}{ Mod } & & \multicolumn{2}{|c|}{$\begin{array}{l}\text { Unstandardized } \\
\text { Coefficients }\end{array}$} & \multirow{2}{*}{$\begin{array}{l}\text { Standardized } \\
\text { Coefficients } \\
\text { Beta }\end{array}$} & \multirow{2}{*}{$\mathrm{t}$} & \multirow{2}{*}{ Sig. } & \multirow{2}{*}{ Note } \\
\hline & & B & $\begin{array}{l}\text { Std. } \\
\text { Error }\end{array}$ & & & & \\
\hline \multirow[t]{4}{*}{1} & (Constant) & 49,661 & 7,795 & & 6,371 & 0,000 & \\
\hline & $\begin{array}{l}\text { Professional } \\
\text { Skeptisism }\end{array}$ & $-0,209$ & 0,087 & $-0,281$ & $-2,402$ & 0,019 & Significant \\
\hline & $\begin{array}{l}\text { Organizational } \\
\text { professional conflict } \\
\text { Performance }\end{array}$ & 0,086 & 0,176 & 0,094 & 0,491 & 0,625 & Not significant \\
\hline & Evaluation & $-0,130$ & 0,088 & $-0,270$ & $-1,484$ & 0,142 & Not Significant \\
\hline
\end{tabular}

Dependent Variable: Dysfunctional Audit Behavior

In step 2, professional skepticism affected the dysfunctional behavior of auditors but showed a negative direction so that they could not fulfill the mediation requirements of Baron and Kenny. Overall, the results of this study indicated that professional skepticism significantly influenced audit judgment, professional skepticism also significantly influenced auditor dysfunctional behavior, but auditor dysfunctional behavior could not mediate the effect of professional skepticism on audit judgment.

In step 2, professional organizational conflict did not affect the auditor's dysfunctional behavior so that it could not fulfill the mediation requirements of Baron and Kenny. Overall, the results of this study indicated that professional organizational conflict had a significant effect on audit judgment, but professional organizational conflict did not affect the auditor's dysfunctional behavior so that the auditor's dysfunctional behavior could not mediate the influence of professional organizational conflict on audit judgment.

In step 2, performance evaluation did not affect the auditor's dysfunctional behavior so that it could not fulfill the mediation requirements of Baron and Kenny. Overall, the results of this study indicated that performance evaluation had a significant effect on audit judgment, but performance evaluation did not affect auditor dysfunctional behavior so that auditor dysfunctional behavior could not mediate the effect of performance evaluation on audit judgment.

Table 3 test result: Effects of Dysfunctional Audit Behavior to Audit Judgment

\begin{tabular}{|c|c|c|c|c|c|c|c|c|}
\hline \multirow[b]{2}{*}{ Model } & & & \multicolumn{2}{|c|}{$\begin{array}{l}\text { Unstandardized } \\
\text { Coefficients }\end{array}$} & \multirow{2}{*}{$\begin{array}{l}\text { Standardized } \\
\text { Coefficients } \\
\text { Beta }\end{array}$} & \multirow{2}{*}{$\mathrm{t}$} & \multirow{2}{*}{ Sig. } & \multirow{2}{*}{ Note } \\
\hline & & & B & $\begin{array}{l}\text { Std. } \\
\text { Error }\end{array}$ & & & & \\
\hline \multirow[t]{2}{*}{1} & (Constant) & & 35,259 & 2,298 & & 15,341 & 0,000 & \\
\hline & $\begin{array}{l}\text { Dysfunctional } \\
\text { Behavior }\end{array}$ & Audit & $-0,173$ & 0,091 & $-0,209$ & $-1,896$ & 0,062 & Significant \\
\hline
\end{tabular}

Dependent Variable: Audit Judgment

Based on the statistical analysis above, the probability value of auditor dysfunctional behavior was 0.062 and smaller than $\alpha=0.10$. The value of $\beta$ auditor dysfunctional behavior was 0.207 and had a negative effect. Based on these results, it could be concluded that auditor dysfunctional behavior had a significant and negative effect on audit judgment. These results indicated that if the auditor who performed the audit in accordance with the procedures and audit programs which had been made, the auditor would work on the audit correctly and would reject deviant behavior so that it could produce a good audit judgment.

The results of this study supported cognitive theories which had the ability to explain or understand human cognitive processes. Auditors who were able to carry out their duties in accordance with the audit program that had been made would choose to behave functionally, and conversely the auditor who chose not to carry out in accordance with the audit program would prefer to behave dysfunctionally (Kristianti, 2012).

The table below presents a summary of research results based on the mediation requirements adopted from Baron and Kenny: 
Table 4: Summary of Mediation Test Results

\begin{tabular}{|l|l|l|l|l|l|l|l|l|}
\hline \multirow{2}{*}{ Variable } & \multicolumn{2}{|l|}{ Stage 1 } & Stage 2 & \multicolumn{2}{l|}{ Stage 3 } & \multicolumn{2}{l|}{ Stage 4 } \\
\cline { 2 - 10 } & $\beta$ & Sig. & $\beta$ & Sig. & $\beta$ & Sig. & $\beta$ & Sig. \\
\hline $\begin{array}{l}\text { Professional } \\
\text { Skepticism (PS) }\end{array}$ & 0.820 & 0.000 & -0.281 & 0.019 & 0,829 & 0.000 & 0,829 & 0.000 \\
\hline $\begin{array}{l}\text { Organizational- } \\
\text { Profesional Conflict } \\
\text { (OPC) }\end{array}$ & 0.267 & 0.007 & 0,094 & 0.625 & 0.264 & 0.008 & 0.264 & 0.008 \\
\hline $\begin{array}{l}\text { Performance } \\
\text { Evaluation (PE) }\end{array}$ & -0.276 & 0.003 & -0.270 & 0.142 & -0.268 & 0.005 & -0.268 & 0.005 \\
\hline $\begin{array}{l}\text { Auditor's } \\
\begin{array}{l}\text { Dysfunctional Behavior } \\
\text { (DAB) }\end{array}\end{array}$ & & & & & & & & \\
\end{tabular}

The final step of mediation testing based on the Baron and Kenny model showed that auditor dysfunctional behavior could not mediate the effect of performance evaluation on audit judgment because it did not fulfill mediation requirements.

\section{Conclusion}

This research was conducted to empirically prove the effect of professional skepticism, organizational professional conflict and performance evaluation on audit judgment with auditor dysfunctional behavior as a moderation variable. The results of the study indicated that professional skepticism, organizational professional conflict, and performance evaluation had significant and positive effect on audit judgment, but the auditor's dysfunctional behavior could not mediate the influence of professional skepticism, organizational-professional conflict and performance evaluation of audit judgment.

The results of this study have several implications for audit practices. In particular, this study found that professional skepticism had an influence on audit judgment and auditor dysfunctional behavior. The next implication of this research was that professional organizational conflict and performance evaluation also had a significant influence on audit judgment. While performance evaluation was also considered an important tool used to control audit quality. When a performance evaluation was given to the auditor and obtained negative feedback, this would indirectly put pressure to improve performance in the next period and negative feedback provided by the auditor would generally lead to a less ethical assessment.

For further research, researcher suggested using interviews to retrieve data, because the answer from the questionnaire is still doubtful, because the researcher could not directly see the respondent's reaction when filling out the questionnaire. In addition, the next researcher can collect data at a time so that it can multiply respondents so that the results of the study can be concluded more generally

\section{References}

Aghazadeh, Sanaz. (2012). Expressed confidence and skepticism: The effect of expressed confidence on auditor judgments: The University of Oklahoma.

Andiola, Lindsay M. (2014). Performance feedback in the audit environment: A review and synthesis of research on the behavioral effects. Journal of Accounting Literature, 33(1-2), 1-36.

Bandura, Albert and Cervone, Daniel. (1986). Differential engagement of self-reactive influences in cognitive motivation. Organizational behavior and human decision processes, 38(1), 92-113.

Baron, Reuben M dan Kenny, David A. (1986). The moderator-mediator variable distinction in social psychological research: Conceptual, strategic, and statistical considerations. Journal of personality and social psychology, 51(6), 1173.

Beekes, Wendy, Otley, David and Ururuka, Valentine. (2014). Factors influencing quality threatening behaviour in a big four accounting firm.

Fakhara, Peyman Tabatabaei and Hoseinzadeh, Ali. (2016). Investigate the effect of organizational commitment and professional commitment on dysfunctional behavior of auditors. Management, 3(1), 1-12.

Ferry, Laurence, Zakaria, Zamzulaila, Zakaria, Zarina and Slack, Richard. (2017). Watchdogs, helpers or protectors? - Internal auditing in Malaysian Local Government. Paper presented at the Accounting Forum.

Hair, J, Black, W, Babin, B and Anderson, R. (2010). Multivariate Data Analysis: A Global Perspective. New Jersey: Pearson Education.

Heyrani, Forough, Banimahd, Bahman and Roudposhti, Fereydoun Rahnamayeh. (2016). Investigation of the Effect of Auditors' Professionalism Levels on their Judgment to Resolve the Conflict between Auditor and Management. Procedia Economics and Finance, 36, 177-188.

Hurtt, R Kathy. (2010). Development of a scale to measure professional skepticism. Auditing: A Journal of Practice \& Theory, 29(1), 149-171. 
Ismail, Fikri. (2015). Pengaruh Tipe Kepribadian, Pengalaman dan Penerimaan Perilaku Disfungsional Terhadap Audit Judgement. Esensi: Jurnal Bisnis dan Manajemen, 5(2).

Iswari, Tabita Indah and Kusuma, IndraWijaya. (2013). The effect of organizational-professional conflict towards professional judgment by public accountant using personality type, gender, and locus of control as moderating variables. Review of Integrative Business and Economics Research, 2(2), 434.

Kartikasari, Rima Novi, Irianto, Gugus and Prihatiningtias, Yeney Widha. (2017). Penerapan Skeptisme Profesional Auditor Internal Pemerintah Dalam Mendeteksi Kecurangan Di Sektor Publik (Studi Pada Auditor Di Bpkp Perwakilan Provinsi Jawa Timur). Jurnal Akuntansi Aktual, 4(2), 77-91.

Khan, Sadaf, Panatik, Siti Aisyah Binti and Saat, Maisarah Binti. (2015). Dysfunctional Audit Behaviors: An Exploratory Study in Pakistan. Research Journal of Applied Sciences, Engineering and Technology, 9(9), 778-785.

Lin, Kenny Z, Fraser, Ian AM and Hatherly, David J. (2003). Auditor analytical review judgement: a performance evaluation. The British accounting review, 35(1), 19-34.

Luthans, Fred, Baack, Donald and Taylor, Lew. (1987). Organizational commitment: Analysis of antecedents. Human relations, 40(4), 219-235.

Mangoting, Yenni. (2004). Tax Planning: Sebuah Pengantar Sebagai Alternatif Meminimalkan Pajak. Jurnal Akuntansi dan Keuangan, 1(1), pp. 43-53.

Mertzlufft, Susan Marie. (2000). The Effects of Audit Review and Audit Risk on Auditors' Justifications and Judgments. University of Illinois at Urbana-Champaign.

Nolder, Christine J. (2012). The Role of Professional Skepticism, Attitudes and Emotions on Auditor's Judgments: Bentley University.

Popova, Velina. (2012). Exploration of skepticism, client-specific experiences, and audit judgments. Managerial Auditing Journal, 28(2), 140-160.

Rizzo, John R, House, Robert J and Lirtzman, Sidney I. (1970). Role conflict and ambiguity in complex organizations. Administrative science quarterly, 150-163.

Rokhmani, Ervina Wafi and Malikah, Anik. (2018). Pengaruh Tipe Kepribadian, Pengalaman Dan Penerimaan Perilaku Disfungsional Terhadap Audit Judgment (Studi Pada Kantor Akuntan Publik Malang). Jurnal Riset Akuntansi, 7(05).

Septiani, Ni Made Indri and Sukartha, I Made. (2017). Pengaruh Kompleksitas Audit Dan Skeptisme Profesional Auditor Pada Penerimaan Perilaku Disfungsional Audit. E-Jurnal Akuntansi, 18.1, 471-499.

Shafer, William E, Park, L Jane and Liao, Woody M. (2002). Professionalism, organizational-professional conflict and work outcomes: A study of certified management accountants. Accounting, Auditing \& Accountability Journal, 15(1), 46-68.

Sofiani, Maria Magdalena Oerip Liana. (2015). Pengaruh Tekanan Ketaatan, Pengalaman Audit, dan Audit Tenure Terhadap Audit Judgement. Tax \& Accounting Review, 4(1), 270.

Svanberg, Jan and Öhman, Peter. (2016). The effects of time budget pressure, organisational-professional conflict, and organisational commitment on dysfunctional auditor behaviour. International Journal of Accounting, Auditing and Performance Evaluation, 12(2), 131-150.

Trotman, Ken T and Yetton, Philip W. (1985). The effect of the review process on auditor judgments. Journal of Accounting Research, 256-267.

Vinciguerra, Barbara M. (2002). Auditor independence: An examination of the effect of self-interest threats and organizational safeguards on auditor judgment.

Winardi, Rijadh Djatu and Permana, Yoga. (2015). Pengaruh skeptisme profesional dan narsisme klien terhadap penilaian auditor eksternal atas risiko kecurangan. Paper dipresentasikan pada acara Simposium Nasional Akuntansi XVIII, Medan.

Yuen, Desmond CY, Law, Philip KF, Lu, Chan and Qi Guan, Jie. (2013). Dysfunctional auditing behaviour: empirical evidence on auditors' behaviour in Macau. International Journal of Accounting \& Information Management, 21(3), 209-226. 